\title{
MAPPING TREES ON FARMLANDS USING OBIA METHOD AND HIGH RESOLUTION SATELLITE DATA: A CASE STUDY OF KORAPUT DISTRICT, ODISHA
}

\author{
R.H. Rizvi ${ }^{1, *}$, Ram Newaj, Shefali Srivastava, Maneesh Yadav \\ ${ }^{1}$ ICAR-Central Agroforestry Research Institute, Jhansi (U.P.), India \\ (rhrizvi, ramnewaj, ecshefali, yadavsd480)@gmail.com
}

Commission III, WG III/10

KEY WORDS: Agroforestry, Object Based Image Analysis, remote sensing, supervised classification, tree mapping.

\begin{abstract}
:
Agroforestry is an integrated self-sustainable land use management system that is not only capable of producing food from marginal agricultural land but also capable of maintaining and improving the quality of environment. Accurate assessment of trees on farmlands i.e. agroforestry would help in determining their contribution in meeting timber demand and also in carbon sequestration vis-a-vis climate change mitigation. In the present, high resolution multispectral satellite imagery (LISS-IV) has been used for mapping and estimating agroforestry area in Koraput district of Odisha. Both supervised and Object based Image Analysis (OBIA) classifications methods have been applied. In case of supervised maximum likelihood method, those pixels are fully captured where trees exist, whereas in OBIA captures trees according to their crown shapes. This proved OBIA method to be better in identification of trees on farmlands (scattered trees, boundary, and block plantations) than supervised method. This can lead to accurate estimation of area under trees in scattered form, in linear form and also in patch form. Improved results were obtained in case of OBIA classification with more than $90 \%$ accuracy. This research implies that remote sensing provide promising tools for evaluating and mapping of agroforestry at district level. Hence, the proposed approach of using high resolution remote sensing data in conjunction with OBIA method would be promising for mapping agroforestry area.
\end{abstract}

\section{INTRODUCTION}

Agroforestry is a land use management system where trees are grown around and among the agricultural crops. The National Agriculture Policy (2000) emphasized the role of agroforestry. The task force of planning commission on Greening India for Livelihood Security and Sustainable Development (2001) also recommended that agroforestry may be promoted for sustainable agriculture. Forest conservation efforts involving reduction of deforestation and degradation may have to increasingly rely on alternatives provided by TOF (Saxena, 1997; Namwata, et al, 2012) in catering to economic demand in forest edges. Various forms of agroforestry exists in India and they occupy considerable area in the whole country.

Remote Sensing Imagery effectively captures various characteristics of the earth's surface but it takes interpreter's knowledge about shape, texture, patterns and site context to derive information about land use activities from information about land cover (Blaschke, 2010). Remote Sensing has become an effective tool for mapping and monitoring of agriculture, forestry, and other natural resources. Geo-spatial technologies viz. Geographic Information System (GIS), Global Positioning System (GPS) and satellite Remote Sensing (RS) are now being widely used in agriculture, forestry, watershed, natural resource management (Rizvi et al. 2013a). GIS and remote sensing applications in agroforestry field include estimating areas for agroforestry (Unruh and Lefebvre 1995; Rizvi et al. 2013b), suitability assessment for agroforestry systems (Bydekerke et al. 1998; Bentrup and Leininger 2002), monitoring agroforestry parks (Bernard and Depommier, 1997). Many studies attempted for mapping agroforestry area using different remote sensing data (Rizvi et al. 2016, Pujar et al. 2016, Tauqeer et al. 2017). Remote sensing technologies can provide a means to classify tree cover and variety of other continuous environmental variables over large spatial extent and moderate temporal extent. Advance object based classifiers have shown promising results for classification of high resolution data for mapping of natural resources (Muller et al. 2004, Bock et al., 2005 and Gamanya et al. 2007, Geneletti and Gorte 2003). With object oriented analysis it is possible to get better results from remote sensing information. That information may be immediately integrated in the GIS allowing the direct realization of vectorial maps (Barrile and Bilotta, 2008). OBIA approach can generate good and repeatable LULC classifications suitable for tree cover assessment in urban areas (Moskal, 2011).

A major problem in estimating area under agroforestry is lack of procedures for delineating the area influenced by trees in a mixed stand of trees and crops. The objective of this study was to explore the potential of high resolution data for identification of trees on farmlands and delineation of agroforestry. For this purpose, supervised and object oriented method of classification have been applied and results were compared.

\section{STUDY AREA}

Koraput district is located in the Southern Odisha state of India (Figure 1). The district lies between $18^{\circ} 13^{\prime}$ to $19^{\circ} 10^{\prime}$ north latitude and between $82^{\circ} 5^{\prime}$ to $83^{\circ} 23^{\prime}$ east longitude. Koraput is dependent on agricultural activities. The climate condition of the district is warm and humid. Average annual rainfall is 1567 $\mathrm{mm}$.

\section{DATA USED}

\subsection{Satellite Data}

Multispectral remote sensing images of RS-2A, LISS IV (resolution-5.8 m) were procured from National Remote Sensing Centre, Hyderabad. LISS IV scenes of path and rows 103-59 (A, B, C, D), 103-60 B, 104-59(A, C, D) \& 104-60A

\footnotetext{
* Corresponding author
} 
(Date of pass- March, 2017) for Koraput district were analyzed for both pixel based and object based classification. The LISSIV sensor has three band in different region of EMR (b2: Green, b3: Red, b4: NIR). Preprocessing of these scenes includes layer stacking, mosacing and sub setting with district boundary. Shape file of district boundary was obtained from Survey of India, Dehradun.

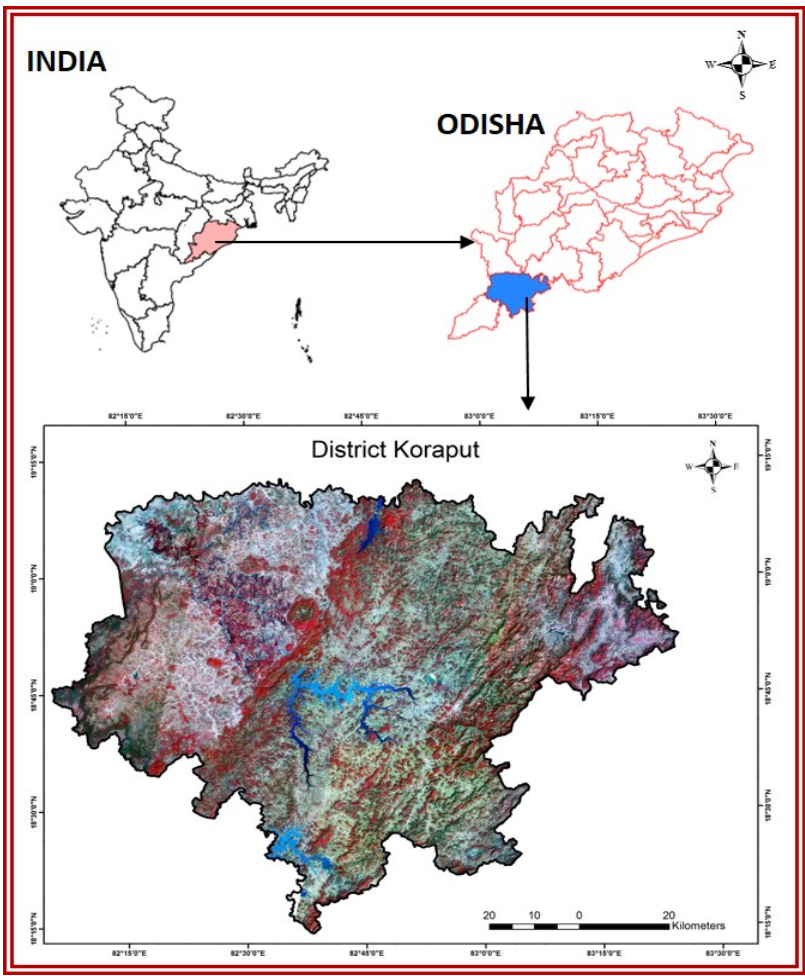

Figure 1. Location map of Koraput district

\begin{tabular}{|l|l|l|l|}
\hline $\begin{array}{l}\text { Spectral } \\
\text { Bands (nm) }\end{array}$ & $\begin{array}{l}\text { Swath } \\
\text { Width }\end{array}$ & $\begin{array}{l}\text { Spatial } \\
\text { Resolution }\end{array}$ & $\begin{array}{l}\text { Radiometric } \\
\text { Resolution }\end{array}$ \\
\cline { 1 - 2 } b2: $520-590$ & & & \\
\cline { 1 - 1 } b3: $620-680$ & $70 / 23 \mathrm{~km}$ & $5.8 \mathrm{~m}$ & $10 \mathrm{bit}$ \\
\cline { 1 - 1 } b4: $770-860$ & & & \\
\hline
\end{tabular}

Table 1. Specifications of LISS-IV sensor data

\subsection{Reference Data \& Accuracy}

Reference data on different land uses was collected from farmer's fields and the agroforestry plots were also tracked by GPS. This reference data was used for signature creation as well as accuracy assessment of land use land cover classification of the study area. Accuracy of land use land cover (LULC) was assessed by error matrix and kappa coefficient.

\section{METHODOLOGY}

Remote sensing data were visually and digitally interpreted using the ERDAS 2015 and ArcGIS software 10.4 for processing, analysis and integration of spatial data. IMAGINE Objective tools of ERDAS Imagine 2015 software were employed for different feature detection and extraction.

\subsection{Supervised Classification}

Maximum Likelihood Classifier (MLC) of supervised method was applied for the assessment of land uses land cover (LULC) in the district. Supervised classification have a sequence of operations 1. Defining the area of interest (AOI) or training samples 2. Extraction of signatures 3. Classification of remote sensing image. MLC consider both the variance and covariance of the $\mathrm{DN}$ values of the training sets based on their spectral signatures. Koraput district was classified into nine LULC classes viz. agroforestry, cropland, plantation, forest, degraded forest, wasteland, built-ups, water bodies, and sandy area (Figure 2).

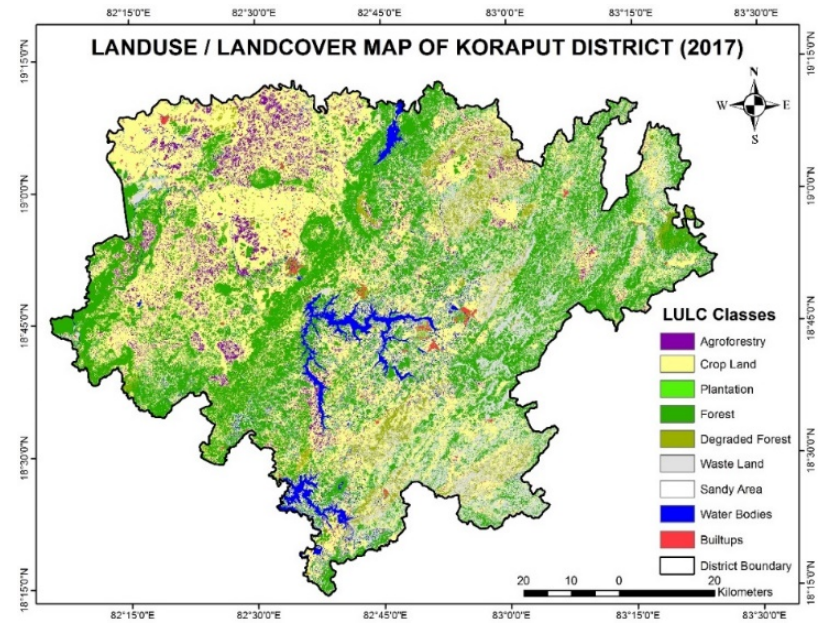

Figure 2. Land use/ land cover map of Koraput district

\subsection{Accuracy Assessment}

Accuracy of LULC was assessed by error matrix also known as confusion matrix and by Kappa coefficient. Error matrix defines the relationship between reference data (ground truth) and the corresponding results of automated classification (Appendix).

4.2.1 Overall Accuracy (OA): OA of the classification is determined by dividing the total no of correctly classified points by the total no of points.

4.2.2 Producer Accuracy (PA): PA indicates that how well the training sets pixels of a given cover type are classified.

4.2.3 User Accuracy (UA): UA of the classification is determined by dividing the no of correctly classified pixels in each category by the total no of pixels that were classified in that category.

4.2.3 Kappa Coefficient: Kappa Coefficient is a multivariate technique for accuracy assessment (Jensen, 1996). An overall Kappa coefficient of 0.783 was obtained which is rated as substantial for this study.

\subsection{OBIA Classification}

Agricultural land including cropland and fallow land, and agroforestry area was masked from false color composite (FCC) with the help of LULC of the district. Object Based Image Analysis (OBIA) was applied on agricultural area because agroforestry exist on agricultural land only and our objective was 
to capture trees on farmlands. The methodology for both the classification methods is shown in Figure 3. In this study the target object i.e. agroforestry was delineated in the form of linear, scattered and block patterns (Figure 4). Accuracy assessment of agroforestry class was assessed on the basis of 135 ground check points.

4.3.1 Raster pixel processor: First step is the processing of pixels with NDVI and multi-bayesian network. Spectral information along with NDVI were used as inputs for generation of spectral feature probability layer by using training pixels. Defining the training areas including trees as well as background pixels for computing the pixel cue matrix. Pixel probability layer were created which defines the object of interest i.e. Trees.

Higher probability values are assigned to those pixels whose values are similar to the ones of pixels in the non- background training samples. Lower probability values are assigned to those pixels whose values are either similar to the ones of pixels in the background training samples or significantly different from the values of pixels in the non-background training samples.

4.3.1 Raster object creator: Threshold/Clump was applied on a pixel probability layer. It keeps only those pixels which have Probability greater than or equal to threshold value and it converts the remaining pixels in $(0,1)$. Then performs a contiguity operation (clump) on the binary values of 1 . It then converts the pixel probability layer to raster object layer. For the study area the value of threshold was chosen to be 0.50 . Lowering the threshold led to inclusion of some non-tree pixels.

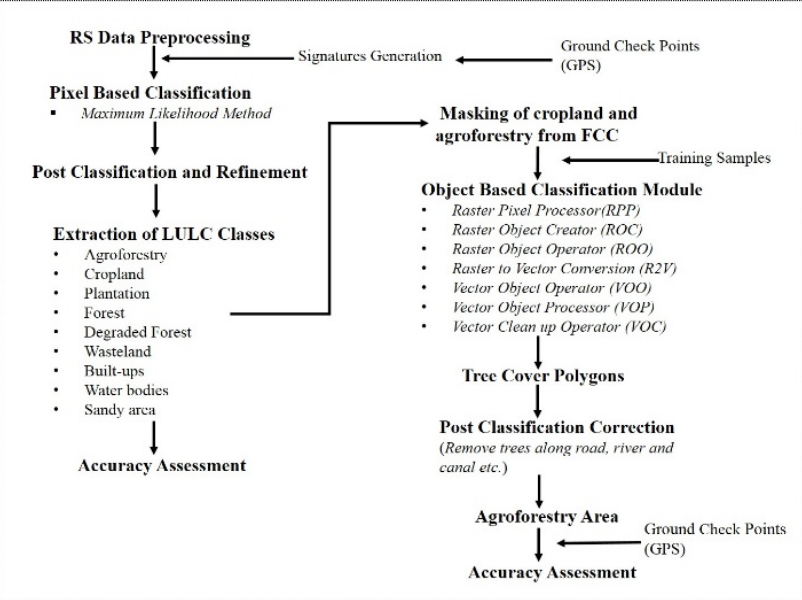

Figure 3. Steps involved in Agroforestry Mapping

4.3.2 Raster object operator: This operator removes all the raster objects whose zonal probability mean is less than the specified minimum probability. In this case the probability filter was chosen at 0.75 .

4.3.3 Raster to vector conversion: Raster object created in previous step were converted to the polygon using polygon trace.
4.3.4 Vector object operator: After polygon conversion the Smooth filter was applied to smoothen the boundaries of trees polygons. Smoothening factor of 0.5 was chosen which was found to be optimum.

4.3.5 Vector clean-up operator: Cleaning of vector layers are done on ArcGIS by online visual interpretation (for agroforestry) to remove scrub land, trees along roads, trees along river/ canal side and erroneous vector object if any.

4.3.6 Accuracy Assessment: Mapping accuracy (Hebbar et al., 2014) was carried out with the ground truth points.

$$
\mathrm{MA}=\frac{\text { No of correctly classified GT points }}{\text { Total no of GT points }} * 100
$$

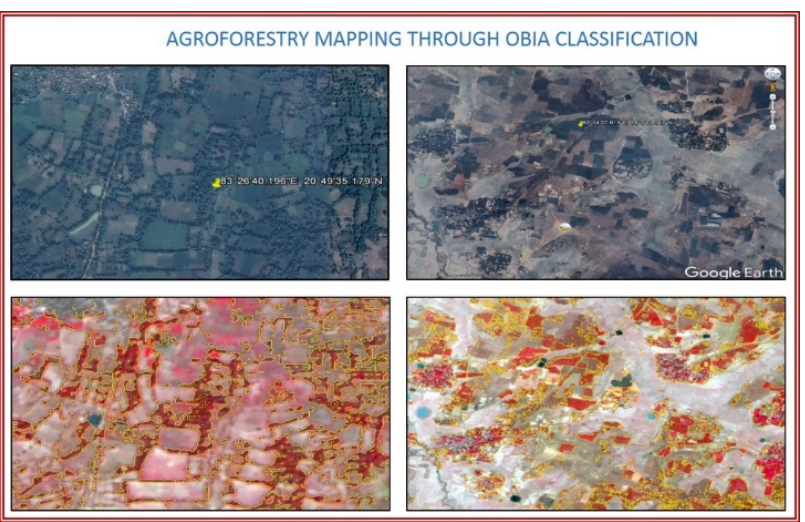

Figure 4. Delineation of Linear, Single and Block Plantations

\section{RESULTS}

In case of maximum likelihood classifier (MLC), area under agroforestry was estimated to be 31795.28 ha $(3.80 \%)$. The overall accuracy of LULC comes out to be $80.81 \%$ with kappa coefficient of 0.783 using MLC. While using OBIA (on agricultural land) agroforestry area was estimated to be 42978.55 ha (5.14\%) (Table 3). Very good accuracy of $91.2 \%$ was achieved in agroforestry class by OBIA classification. The results obtained by MLC and OBIA methods were compared in case of agroforestry (Figure 5). In case of supervised classification, those pixels are fully captured where trees exist, whereas OBIA captures trees according to their crown shapes. This lead to accurate estimation of area under trees in scattered, in linear and also in patch form. Therefore, OBIA could be an appropriate method for mapping all types of agroforestry (scattered trees, boundary and block plantations) existing on farmlands. Thus, OBIA method may be a useful and promising technique for classifying object from high resolution satellite imagery.

The developed feature extraction model detects the tree objects in images as polygon. The challenges in object oriented classification is that, identification and classification of trees require in-depth understanding of factors affecting the spectral information of trees. For extraction of trees, the polygon based approach shows the best result. Trees are quantitatively extracted by Bayesian network model parameters and calibrated by using probabilistic approach. This model is robust and can be applied to other areas (subsets). 


\begin{tabular}{|l|r|r|c|c|}
\hline \multicolumn{5}{|c|}{ KORAPUT LULC \& OBIA Stats } \\
\hline & \multicolumn{2}{|c|}{ MLC } & \multicolumn{2}{c|}{ OBIA } \\
\hline LULC Classes & \multicolumn{1}{|c|}{ Area (ha) } & Area (\%) & Area (ha) & Area (\%) \\
\hline Agroforestry & 31795.28 & 3.80 & 42978.55 & 5.14 \\
\hline Crop land & 322367.25 & 38.53 & $\ldots \ldots \ldots$ & $\ldots \ldots \ldots$ \\
\hline Plantation & 3167.41 & 0.38 & $\ldots \ldots \ldots$ & $\ldots \ldots \ldots$ \\
\hline Forest & 261348.25 & 31.24 & $\ldots \ldots \ldots$ & $\ldots \ldots \ldots$ \\
\hline Degraded forest & 24930.94 & 2.98 & $\ldots \ldots \ldots$ & $\ldots \ldots \ldots$ \\
\hline Waste land & 151472.64 & 18.11 & $\ldots \ldots \ldots$ & $\ldots \ldots \ldots$ \\
\hline Sandy area & 269.69 & 0.03 & $\ldots \ldots \ldots$ & $\ldots \ldots \ldots$ \\
\hline Water body & 33182.19 & 3.97 & $\ldots \ldots \ldots$ & $\ldots \ldots \ldots$ \\
\hline Built ups & 8087.92 & 0.97 & $\ldots \ldots \ldots$ & $\ldots \ldots \ldots$ \\
\hline $\begin{array}{l}\text { Geographical } \\
\text { Area (ha) }\end{array}$ & $\mathbf{8 3 6 6 2 1 . 5 7}$ & & & \\
\hline
\end{tabular}

Table 3. Estimated agroforestry area in Koraput district

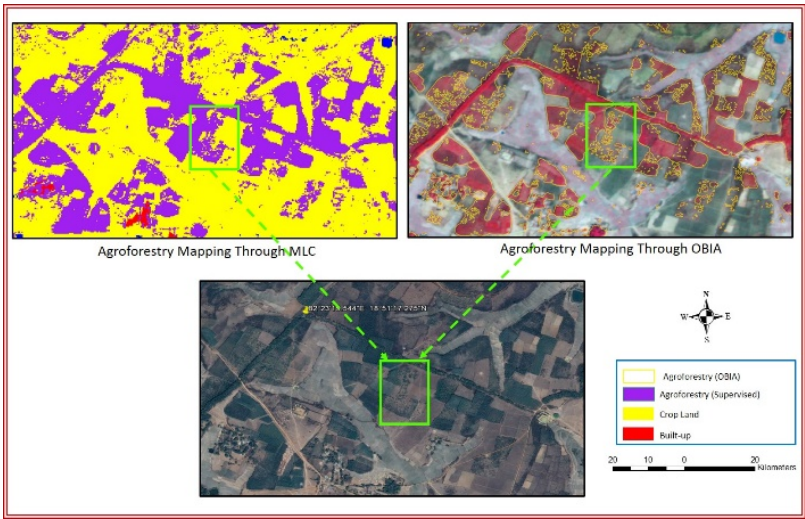

Figure 5. Agroforestry mapping through OBIA and MLC

\section{DISCUSSION}

Object oriented image classification method is useful and promising method of classifying objects from high resolution satellite images. The method segments the image pixels into objects and utilizes the texture and contexture information of the object rather than only using spectral information relied upon by traditional methods. IMAGINE Objective provides a high accuracy function for tree extraction when one is dealing with cluster of individual tree crowns. By using cue parameters like color, tone, texture, orientation, etc. the spectral difference between trees and other features were able to be detected (Lehbrass and Wang 2010). Based on training samples, the trees were quantitatively extracted by means of probability of Bayesian Network on Single Feature Probability (SFP) function. With object oriented analysis, it is possible to get better result from high resolution remote sensing.

\section{CONCLUSIONS}

The current study demonstrated the suitability of object based classification for agroforestry mapping in Koraput district using high resolution (LISS-IV) data. Object Based Image Analysis (OBIA) method gave better results than maximum likelihood classifier (MLC) method as far as mapping of trees outside forest is concerned. Thus, OBIA method would prove to be more accurate method for mapping agroforestry using high resolution remote sensing data. Further research needs to be done for the possibility of identification and mapping of tree species on farmlands using spectral and textural information.

\section{ACKNOWLEDGEMENT}

Authors are very grateful to Indian Council of Agricultural Research, New Delhi for funding NICRA project. Authors are also thankful to Director, CAFRI, Jhansi for extending his support for carrying out this study.

\section{REFERENCES}

Ahmad, T., Sahoo, P.M. and Jally, S.K., 2016. Estimation of area under agroforestry using high resolution satellite data. Agroforestry Systems, 90, pp. 289-303.

Barrile, V. and Bilotta, G., 2008. An application of remote sensing: Object-oriented analysis of Satellite data. The International Archives of the Photogrammetry, Remote Sensing and Spatial Information Sciences, vol. XXXVII, pp. 107-113.

Bentrup, G. and Leininger, T., 2002. Agroforestry: mapping the way with GIS. Journal of Soil Water Conservation, 57, pp. 148A-153A.

Bernard, G. and Depommier, D., 1997. The systematic approach and the role of GIS in the characterization and monitoring of agroforestry parks. XI World Forestry Congress, Antalya, Turkey, 13 to 22 October 1997. pp. 1-87.

Blaschke, T., 2010. Object based image analysis for remote sensing. ISPRS Journal of Photogrammetry and Remote Sensing, 65, pp. 2-16.

Bock, M., Xofis, P., Mitchley, J., Rossner, G. and M. Wissen, 2005. Object-oriented methods for habitat mapping at multiple scales- Case studies from Northern Germany and Wye Downs. UK Journal for Nature Conservation, 13, pp. 75-89.

Bydekerke, L., Van Ranst, E., Vanmechelen, L., and Groenemans, R., 1998. Land suitability assessment for cherimoya in southern Ecuador using expert knowledge and GIS. Agriculture Ecosystem \& Environment, 69, pp. 89-98.

ERDAS (2009) Imagine Objective, User's Guide.

Gamanya, R., Maeyer, P.D. and Dapper, M.D., 2007. An automated satellite image classification design using object oriented segmentation algorithms: A move towards standardization. Expert Systems with Applications, 32, pp. 616624.

Geneletti, D. and Gorte, B.G.H., 2003. A method for objectoriented land covers classification combining Landsat TM data and aerial photographs. International Journal of Remote Sensing, 24(6), pp. 1273-1286.

Hebbar, R., Ravishankar, H.M., Trivedi, S., Subramonium, S.R., Raj, U. and Dadhwal, V.K., 2014. Object oriented classification of high resolution data for inventory of Horticulture crops. The International Archives of the Photogrammetry, Remote Sensing and Spatial Information 
Sciences, XL-8, ISPRS Technical Commission VIII Symposium, Hyderabad, India.

Jensen, J.R., 1996. Introductory Digital Image Processing: A Remote Sensing Perspective. $2^{\text {nd }}$ Edition, Prentice Hall, Inc., Upper Saddle River, NJ.

Lehbrass, B., Wang, J.F., 2010. Techniques for object based classification of urban tree cover from high resolution multispectral imagery. Canadian Journal of Remote Sensing, 36, pp. 287-S297.

Moskal, L.M., Styers, D.M., Halabisky, M., 2011. Monitoring Urban Tree Cover Using Object-Based Image Analysis and Public Domain Remotely Sensed Data. International Journal of Remote Sensing, 3, pp. 2243-2262.

Mueller, M., Segl, K. and Kaufmann, H., 2004. Edge and region- based segmentation technique for the extraction of large, man- made objects in high resolution satellite imagery. Pattern Recognition, 37, pp. 1619-1628.

Namwata, B.M.L., Masanyiwa Z.S. and Mzirai, O.B., 2012. Productivity of Agroforestry Systems and its Contribution to Household Income among Farmers in Lushoto District, Tanzania. International Journal of Physical and Social Sciences, 2(7), pp. 2249-5894.

Pujar, G.S., Dadhwal, V.K., Murthy, M.S.R., Trivedi, S., Reddy, P.M. and Swapna, D., 2016. Geospatial approach for
National level TOF assessment using IRS high resolution imaging: Early results. Journal of the Indian Society of Remote Sensing, 44(3), pp. 321-333.

Rizvi, R.H., Dhyani, S.K. and Newaj, Ram, 2013a. Harnessing Geo-spatial Technologies for Agroforestry Development in India. In: Geospatial Technologies for Natural Resources Management (Eds.: Soam et al.), New India Publishing Agency, N. Delhi, pp. 279-290.

Rizvi, R.H., Dhyani, S.K., Newaj, R., Saxena, A. and Karmakar, P.S., 2013b. Mapping extent of agroforestry area through remote sensing: issues, estimates and methodology. Indian Journal of Agroforestry, 15(2), pp. 26-30.

Rizvi, R.H., Newaj, R., Karmakar, P.S., Saxena, A. and Dhyani, S.K., 2016. Remote Sensing analysis of Agroforestry in Bathinda and Patiala districts of Punjab using sub-pixel method and medium resolution data. Journal of the Indian Society of Remote Sensing, 44(4), pp. 657-664.

Saxena, N.C., 1997. The Wood Fuel Scenario and Policy Issues in India. RWEDP Field Document No.49. FAO. Bangkok.

Unruh, J.D. and Lefebvre, P.A., 1995. A spatial database for estimating areas for agroforestry in Sub-Saharan Africa: aggregation and use of agroforestry case studies. Agroforestry Systems, 32, pp. 81-96.

\section{APPENDIX}

\begin{tabular}{|c|c|c|c|c|c|c|c|c|c|c|}
\hline Classified & $\begin{array}{l}\text { Agro- } \\
\text { forestry }\end{array}$ & $\begin{array}{l}\text { Crop } \\
\text { land }\end{array}$ & Plantation & Forest & $\begin{array}{l}\text { Degraded } \\
\text { forest }\end{array}$ & $\begin{array}{l}\text { Waste } \\
\text { land }\end{array}$ & $\begin{array}{l}\text { Sandy } \\
\text { area }\end{array}$ & $\begin{array}{l}\text { Water } \\
\text { body }\end{array}$ & $\begin{array}{l}\text { Built } \\
\text { ups }\end{array}$ & Total \\
\hline Agroforestry & 25 & 5 & 7 & 1 & 1 & 0 & 0 & 0 & 0 & 39 \\
\hline Crop land & 3 & 25 & 4 & 1 & 1 & 2 & 0 & 0 & 1 & 37 \\
\hline Plantation & 3 & 4 & 20 & 1 & 2 & 0 & 0 & 0 & 0 & 30 \\
\hline Forest & 2 & 1 & 2 & 37 & 3 & 1 & 0 & 0 & 0 & 46 \\
\hline Degraded forest & 2 & 1 & 1 & 3 & 35 & 0 & 0 & 0 & 0 & 42 \\
\hline Waste land & 0 & 1 & 0 & 0 & 1 & 32 & 1 & 3 & 1 & 39 \\
\hline Sandy area & 0 & 0 & 0 & 0 & 0 & 0 & 20 & 1 & 0 & 21 \\
\hline Water body & 0 & 1 & 0 & 0 & 0 & 2 & 1 & 38 & 3 & 45 \\
\hline Built ups & 0 & 2 & 0 & 1 & 1 & 3 & 0 & 3 & 35 & 45 \\
\hline TOTAL & 35 & 40 & 34 & 44 & 44 & 40 & 22 & 45 & 40 & 344 \\
\hline
\end{tabular}

Error matrix of LULC classification

\begin{tabular}{|r|l|r|r|r|r|}
\hline $\mathbf{S .}$ No. & Classified Data & $\begin{array}{l}\text { COMISSION } \\
\text { ERROR (CE \%) }\end{array}$ & $\begin{array}{l}\text { OMISSION } \\
\text { ERROR (OE \%) }\end{array}$ & $\begin{array}{l}\text { Users Accuracy (\%) } \\
\text { Producers } \\
\text { Accuracy (\%) }\end{array}$ \\
\hline $\mathbf{1}$ & Agroforestry & $35.90 \%$ & $28.57 \%$ & $71.43 \%$ & $64.10 \%$ \\
\hline $\mathbf{2}$ & Crop land & $32.43 \%$ & $37.50 \%$ & $62.50 \%$ & $97.30 \%$ \\
\hline $\mathbf{3}$ & Plantation & $33.33 \%$ & $41.18 \%$ & $58.82 \%$ & $66.67 \%$ \\
\hline $\mathbf{4}$ & Forest & $21.62 \%$ & $15.91 \%$ & $84.09 \%$ & $80.43 \%$ \\
\hline $\mathbf{5}$ & Degraded forest & $16.67 \%$ & $20.45 \%$ & $79.55 \%$ & $83.33 \%$ \\
\hline $\mathbf{6}$ & Waste land & $17.95 \%$ & $20.00 \%$ & $80.00 \%$ & $82.05 \%$ \\
\hline $\mathbf{7}$ & Sandy area & $4.76 \%$ & $9.09 \%$ & $90.91 \%$ & $95.24 \%$ \\
\hline $\mathbf{8}$ & Water body & $15.56 \%$ & $15.56 \%$ & $84.44 \%$ & $84.44 \%$ \\
\hline $\mathbf{9}$ & Built ups & $22.22 \%$ & $12.50 \%$ & $87.50 \%$ & $77.78 \%$ \\
\hline
\end{tabular}

Category wise accuracy assessment statistical parameters 